\title{
LEGITIMITA AUTOMATIZOVANÉHO ZPRACOVÁNÍ JUDIKATURY ${ }^{1}$
}

\author{
RADIM POLČÁK ${ }^{2}$
}

\begin{abstract}
ABSTRAKT
Moderní metody zpracování velkých datových souborů umožňují mimo jiné provádět i detailní a sofistikované analýzy judikatury. Vedle základních vzájemných vazeb a odkazů lze analyzovat v prakticky neomezeném rozsahu i nejrůznější formální a obsahové aspekty soudních rozhodnutí v libovolně širokých souvislostech. Tento př́spěvek se v kontextu aktuálního vývoje př́slušných technologii zabývá informační kvalitou soudního rozhodnutí a jejím vztahem $k$ informačním efektům užití judikatury $v$ kontinentálně evropské právní kultuře. V diskusní části tohoto př́spěvku pak je argumentována legitimita restriktivního regulatorního př́stupu $k$ analytickým nástrojům, jejichž užití by mohlo vést $k$ omezení nezávislosti soudce.
\end{abstract}

\section{KLÍČOVÁ SLOVA}

Judikatura, precedens, dělba moci, právní informatika, promulgace, prediktivní analýza, profilování

\section{ABSTRACT}

Big data technologies allow for detailed and sophisticated analyses of case-law. Besides basic mutual relations or links, it is also possible to analyse various formal and material aspects of court decisions in unprecedented range and

1 Tento př́spěvek vznikl jako součást plnění výzkumného projektu č. GA17-20645S.

2 doc. JUDr. Radim Polčák, Ph.D., Ústav práva a technologií Právnické fakulty Masarykovy univerzity, e-mail: radim.polcak@law.muni.cz 
depth. This paper aims at discussing, in the context of current technological developments, information properties of court decisions and their relations to information effects of case-law in continental European legal culture. Consequently, the text argues in favour of legitimacy of restrictive regulatory approaches to analytical tools that might lead to limitations of judicial independence.

\section{KEYWORDS}

Case-law, precedent, distinction of powers, legal informatics, promulgation, predictive analysis, profiling

\section{PRÁVNÍ INFORMATIKA A PRAKTICKÁ DŮLEŽITOST JUDIKATURY}

Pro právní informatiku je judikatura jednou z komponent informačního systému práva. Cílem zpracování judikatury je tedy informační efekt jejího užití.

Předmětem tohoto prríspěvku budou externí zdroje informační kvality soudního rozhodnutí, které je publikováno a následně automatizovaně zpracováno. Budeme si všímat především způsobů, kterými je soudnímu rozhodnutí dodávána nebo naopak odebírána jeho informační kvalita a způsobilost přispívat $\mathrm{k}$ ultimativní teleologii práva, tj. informovat (organizovat) společnost. $\mathrm{V}$ závěru se pak budeme zabývat relativně novým druhem hloubkové prediktivní analýzy soudních rozhodnutí a v kontextu dostupných znalostí o možnostech této technologie se pokusíme formulovat názor na legitimitu a informační efekt aktuálně nejrestriktivnějšího přístupu zvoleného francouzským zákonodárcem.

Perspektiva pohledu na právo jako na informační systém vychází u právní informatiky ze základních myšlenek kybernetiky. Ta vznikla 
v polovině minulého století a jejím základním cílem bylo popsání a napodobení mechanismu, který život používá v boji s entropiî̉.

Kybernetika vycházela $\mathrm{z}$ výsledků filozofie a přírodních věd dosažených na přelomu devatenáctého a dvacátého stoletî́ ${ }^{4}$, přičemž dobře popsanou unikátní vlastností života byla právě jeho způsobilost čelit entropii. Ta se stala i ústředním předmětem zkoumání kybernetiky, nikoli snad z hlediska teleologického ale funkčního.

Zkoumáním procesu zvyšování organizace, tj. snižováním entropie, u živých organismů dospěla kybernetika k poznání nástroje, k jehož originální tvorbě má život jakožto přírodní fenomén unikátní způsobilost. Tímto nástrojem je informace a jednou ze základních premis kybernetiky tak je př́má logická kontradikce entropie a informace. ${ }^{5}$

Původní Wienerova kybernetika byla poměrně vzdálena jejím dnešním inkarnacím majícím spíše technický charakter. Jednalo se totiž o komplexní filozofii, jejímž základním předmětem zkoumání byl život jako př́rodní fenomén. ${ }^{6}$ Dnešní vysoce rozvinuté obory informatiky, robotiky nebo mechatroniky si všímají především technologií, kterými napodobujeme nebo dokonce zdokonalujeme informování v živých organismech. Jedná se tím pádem o aplikované technické formy kybernetiky.

Předmětem kybernetiky však původně byly i základní otázky informování, tj. organizace, z pohledu filozofického nebo sociálně-vědního. Disproporce mezi bouřlivým vývojem aplikovaných forem kybernetiky a její, původně možná i dominantní, filozofickou komponentou, vedou dnes k evidentním důsledkům. Máme totiž $\mathrm{k}$ dispozici vysoce výkonné informační technologie, jejichž užití však ve výsledku často nevede

3 Základním pramenem pro studium kybernetiky je monografie Wiener, N. Cybernetics: Or the Control and Communication in the Animal and the Machine. Cambridge : MIT Press, 1961.

4 Srov. Schrödinger, E. What is Life. Cambridge : Cambridge University Press, 1992. Dílo je volně dostupné $\mathrm{i}$ on-line na adrese $<$ www.home.att.net/ $\sim$ p.caimi/Life.doc $>$.

5 Srov. Wiener, N. Cybernetics: Or the Control and Communication in the Animal and the Machine. Cambridge : MIT Press, 1961, str. 11.

6 Vladimír Neff ve svém slovníku dokonce označuje kybernetiku za filozofii života - viz Neff, V. Filozofický slovník pro samouky aneb Antigorgias. Praha: Mladá fronta, 1993, str.182. 
k informování společnosti. Dokonce se dá při pohledu na řadu současných technologií a služeb informační společnosti velmi zjednodušeně říci, že máme v rukou skvěle funkční a vysoce výkonné nástroje, ale nevíme, k čemu nám mají být dobré.

Právní informatika či právní kybernetika původně vznikla jako aplikovaná forma kybernetiky. Tato disciplína je tedy důsledkem aplikace kybernetické metody na systém práva. Odtud pramení její shora konstatovaný předpoklad, že právo je informační systém, tj. že smyslem práva je informovat, resp. organizovat, společnost. ${ }^{7}$

I v tomto případě vidíme postupný posun od původního komplexního přístupu $\mathrm{k}$ právu jako informačnímu systému $\mathrm{k}$ technickým nástrojům pro zpracování právních dat. Dnes nejvíce viditelnými formami právní informatiky jsou vývoj právních informačních systémů, funkčních pomůcek pro praktikující právníky nebo dokonce systémů způsobilých díky autonomnímu zpracování právně relevantních dat nahrazovat do určité míry některé právnické profese. I zde tedy dospíváme do situace, kdy máme k dispozici vysoce výkonné nástroje pro zpracování právních dat, jejichž použití ale nemusí nutně vždy vést ke skutečné informaci, tj. ke snížení entropie ve společnosti. ${ }^{8}$

Vývoj kybernetiky a právní kybernetiky, jehož důsledkem je současný stav poznání $\mathrm{v}$ oborech informatiky a právní informatiky, je přirozeně motivován relativní jednoduchostí technologického pokroku na poli zpracování dat na jedné straně a vysokou obtížností detekce či identifikace dat způsobilých indukovat informaci na straně druhé. Jakkoli je totiž složité postavit a naprogramovat výkonný právní automat, pořád je to nesrovnatelné jednodušší než rozlišit, která právní data ve výsledku

\footnotetext{
7 Jedním z průkopníků evropské právní kybernetiky, resp. právní informatiky, byl Viktor Knapp - srov. Knapp, V. O možnosti použití kybernetických metod v právu. Praha : Nakladatelství Československé akademie věd, 1963. Vývoj československé právní informatiky shrnuje v dobových souvislostech kapitola Polčák, R. Informační teorie práva, in Bobek, M., Molek, P., Šimíček, V. Komunistické právo v Československu, Brno: Masarykova univerzita, 2009, str. 167.

8 Vývoj právní informatiky za poslední půlstoletí mapuje sborník Paliwala, A. A History of Legal Informatics. Zaragoza : Prensas de Universitarias de Zaragoza, 2010.
} 
povedou k organizaci nebo naopak $\mathrm{k}$ chaotizaci nějakého sociálního systému. ${ }^{9}$

Snaha dnešní právní informatiky tedy $\mathrm{v}$ obecné rovině směřuje k vytvoření, pokud možno, co nejvýkonnějšího nástroje ke zpracování a případně i ke komunikaci právních dat. Př́kladně u právních dat typu zákonného práva jde právní informatice o konstrukci takových mechanismů, které co nejefektivněji zpř́stupní př́islušné zákonné texty jejich cílové skupině.

Celá tato snaha však stojí na velmi snadno zpochybnitelné premise, že totiž veškeré zákonné právo je informací. Pokud by tomu tak skutečně bylo, platila by přímá úměra mezi dostupností zákonného práva a mírou organizace společnosti. Čím snadněji by se adresát zákona mohl seznámit s jeho textem, tím vyšší by byla ve výsledku míra společenské organizace. Tomu by pak odpovídala i objektivní legitimita snahy o co nejefektivnější proces zpracování nebo publikace zákonného práva.

Platnost zákonného práva však nijak přímo nesouvisí s jeho informační kvalitou. Zákon tedy může být dobrý, tj. informovat společnost ve smyslu jejího organizování, ale může být i špatný a vést naopak ke zvýšení míry společenské entropie. Kvalitní nástroj k efektivnímu zpracování textů zákonného práva a jejich bezproblémové distribuci jejich adresátům tedy sice u dobrého zákona posílí jeho informační efekt, u špatného zákona však naopak vede $\mathrm{k}$ posílení jeho chaotického dopadu. ${ }^{10}$

Pokud by měl být účel právního informačního systému $\mathrm{k}$ publikaci zákonného práva identický s původní myšlenkou právní informatiky, tj. fungování práva jako informačního systému, znamenalo by to, že by takový systém měl být schopen rozlišit dobré zákony od špatných. Ty dobré by měl co nejefektivněji komunikovat $\mathrm{k}$ cílové skupině a ty špatné by naopak měl před cílovou skupinou co nejefektivněji tajit.

Požadavek na to, aby se právní informatika zabývala otázkou, jak rozlišit dobrý a špatný zákon, je samozřejmě z podstaty absurdní. Nelze po

\footnotetext{
9 Člověk totiž není vybaven schopností staticky poznat informaci - $\mathrm{k}$ tomu viz dále a podrobněji viz Polčák, R. Internet a proměny práva, Praha: Auditorium, 2012, str. 23.

10 Podrobněji viz Polčák, R. Internet a proměny práva, Praha: Auditorium, 2012, str. 202.
} 
žádné vědní disciplíně, přírodovědné nebo společenské, požadovat nemožné, tj. $v$ tomto případě exaktní ( a tím pádem objektivně ověřitelné) hodnocení informační kvality dat, nota bene a priori, tj. před jejich reálnou aplikací.

Stejně absurdní a dokonale nelegitimní je i představa, že právní informační systém za účelem informování (organizování) společnosti rozlišuje mezi dobrým a špatným zákonem a výsledek tohoto posouzení pak předurčuje metodu zpracování př́islušných zákonných textů. Je pochopitelné, že právní informatika, nemoha řešit otázku informační kvality právních dat, zabývá se objektivně řešitelným problémem, jak data (bez ohledu na jejich kvalitu a způsobilost indukovat informaci) co nejefektivněji zpracovat.

Zatímco je atribut platnosti zákona binární a z hlediska praktického fungování systémů pro zpracování právních dat jen těžko zpochybnitelný, je situace $v$ případě judikatury poněkud odlišná. Judikatura totiž tento atribut nemá, nebơ o ní v naší právní kultuře neuvažujeme jako o absolutně závazné. ${ }^{11}$ Charakter judikatury jakožto pramene práva je namísto toho definován zprostředkovanou argumentační závazností, která nastupuje $\mathrm{v}$ prrípadech intenzivního tlaku rovnosti nebo právní jistoty. ${ }^{12}$

Relativní mnohost a částečně exaktní povaha faktorů praktické důležitosti judikatury ${ }^{13}$ tvoří, společně s praktickou poptávkou, originální zadání pro právní informatiku. Ta totiž sice, podobně jako v případě zákonného práva, nedisponuje metodami k hodnocení informačního potenciálu určitého soudního rozhodnutí, ale díky nástrojům pro zpracování velkého množství dat může exaktními metodami přispět $\mathrm{k}$ indexaci judikatury. Zjednodušeně řečeno tedy může $\mathrm{v}$ tomto případě nabídnout právní informatika nástroje k exaktnímu měření praktické důležitosti soudního rozhodnutí. ${ }^{14}$

\footnotetext{
${ }^{11}$ K pojmu absolutní závaznosti viz Knapp, V. Teorie práva. Praha: C.H. Beck, 1991, str. 149.

12 Podrobně viz Bobek, M., Kühn, Z. a kol. Judikatura a právní argumentace, 2. vyd. Praha: Auditorium 2013, str. 64.

13 Viz tamtéž, str. 111.
} 
Situace, kdy je určitý pramen práva závazný jinak než absolutně, je pro kontinentálně-evropskou právní kulturu založenou na dělbě moci poměrně výjimečná. Judikatura se $\mathrm{v}$ tomto př́padě mechanismem své závaznosti blíží z pohledu právní informatiky právním principům, u nichž rovněž není závaznost binární kategoriî. ${ }^{15}$ Podobně jako právní principy právně platí a zavazují v určité míře, platí a zavazuje v určité míře též judikatura. Na rozdíl od právních principů, kde je míra jejich závaznosti zpravidla otázkou jejich ad hoc intenzity, však může být míra závaznosti (či důležitosti) judikatury přinejmenším zčásti otázkou objektivně definovatelných a logicky souvisejících parametrů. Exaktnost právně informatických metod pak tedy může $\mathrm{v}$ naší právní kultuře částečně kompenzovat netradiční organickou nejistotu ohledně závaznosti judikatury jakožto pramene práva.

\section{INFORMAČNÍ HODNOTA SOUDNÍHO ROZHODNUTÍ}

\section{A JUDIKATURY}

Při exaktním hodnocení praktické důležitosti judikatury je třeba z hlediska právní informatiky rozlišit pojem soudního rozhodnutí jakožto ad hoc výsledku procesu autoritativní aplikace práva a soudního rozhodnutí jakožto součásti judikatury a komponenty informačního systému platného práva.

Prvním hlediskem odlišení je aspekt cílového systému, jehož organizace je ambicí soudního rozhodnutí. To je v kontinentální evropské právní kultuře výstupem procesu autoritativní aplikace práva, $\mathrm{v}$ jehož důsledku vznikají, mění se nebo zanikají práva a povinnosti konkrétního subjektu. Na rozdíl od absolutně závazného pramene práva, typicky zákona, je tedy soudní rozhodnutí bezprostředně závazné a adresované. ${ }^{16}$ To znamená, že

${ }^{14}$ Př́íkladem metody hodnocení praktické důležitosti je Shepardizing. Tato metoda byla pojmenována po svém vynálezci Franku Shepardovi a používá již déle něž sto let při indexaci judikatury v USA. Podrobněji k metodě viz Cole, B. Shepardizing: A Comparison of the Printed Citators and On-Line Shepardizing Services. Legal Reference Services Quarterly. 1988, roč. 7,č. 2-4, str. 261.

15 K metodě nebinárního užití právních principů viz Alexy, R. On the Structure of Legal Principles. Ratio Iuris. 2000, roč. 13 ,č. 3, str. 1 a násl. Z česky psané literatury viz Holländer, P. Filosofie práva. Plzeň : Aleš Čeněk, 2006, str. 158 a násl.

16 Podrobněji viz Knapp, V. Teorie práva. Praha: C.H. Beck, 1991, str. 186. 
ambicí soudního rozhodnutí je bezprostředně informovat (organizovat) cílový systém tvořený jeho adresáty a státem. ${ }^{17}$

Soudní rozhodnutí jako součást judikatury však má informovat zcela jiný cílový systém a též metoda jeho informačního působení není založena na bezprostřední závaznosti. ${ }^{18}$ Informační hodnota soudního rozhodnutí tady nespočívá v bezprostřední organizaci konkrétně definovaného cílového systému (tj. relace státu a účastníků řízení), ale ve zprostředkované organizaci neurčitého okruhu adresátů platného práva. Tento způsob organizace cílového systému je tedy obdobný jako $\mathrm{v}$ případě zákonného práva, nebot konkrétní právní pravidlo $v$ tomto případě nastupuje jako hypotetický důsledek výskytu určitých právních skutečností a najisto může (a nemusí) být jeho závaznost konstatována až následně v procesu autoritativní aplikace práva. ${ }^{19}$ Podobně jako u zákona tedy judikatura generuje obecné právní povinnosti, jejichž konkrétní závaznost může být potvrzena individuálním právním aktem - to ale pouze $\mathrm{v}$ případě, že se příslušná situace stane předmětem vrchnostenského rozhodování.

$\mathrm{Z}$ tohoto rozdílu mezi soudním rozhodnutím jako formou relativně závazného imperativu a soudním rozhodnutím jako formou obecného právního pravidla plyne řada důsledků pro jeho zpracování za užití metod právní informatiky. Pro práci se soudním rozhodnutím v prvním zmíněném případě jsou totiž rozhodující jiné formální znaky, než je tomu v případě druhém.

K jednoduššímu popisu a procesní kvalifikaci relevantních formálních prvků soudního rozhodnutí pro první či druhý typ zpracování lze tyto rozlišit na interní a externí formu. Interní forma se týká textu soudního rozhodnutí, zatímco externí forma je otázkou formálních znaků generovaných vnějším prostředím.

Pro užití soudního rozhodnutí jako relativně závazného zdroje právního imperativu je logicky důležitější jeho interní forma. Z výroku totiž plynou

\footnotetext{
17 Srov. Bobek, M., Kühn, Z. a kol. Judikatura a právní argumentace, 2. vyd. Praha: Auditorium 2013, str. 103.

18 Podrobně viz tamtéž, str. 108.

19 Srov. Kelsen, H. Pure theory of Law, New Jersey: The Lawbook Exchange, 2005, str. 114.
} 
příslušné povinnosti a odůvodnění pak slouží jednak $\mathrm{k}$ vysvětlení výroku vzhledem ke konkrétním skutkovým a právním souvislostem a jednak $\mathrm{k}$ ověření jeho legitimity vưči platnému hmotnému a procesnímu právu. ${ }^{20}$ Externí forma soudního rozhodnutí sice rovněž zahrnuje z hlediska své relativní závaznosti podstatné prvky, typicky $\mathrm{v}$ př́padě, kdy je potvrzeno nebo zrušeno $v$ nějakém revizním řízení (odvolání, dovolání, kasaci). Ty mají ale obvykle jednoduchou povahu a dají se snadno automatizovaně zpracovat.

Vnější forma soudního rozhodnutí je naproti tomu v př́padě jeho zpracování jakožto komponenty judikatury nesrovnatelně složitější. Vedle jednoduchých formálních kategorií, jakými jsou typicky právní moc nebo vykonatelnost, je třeba pracovat $s$ řadou dalších typů dat, které mohou ve výsledku výrazně ovlivnit praktickou jeho důležitost nebo technickou dostupnost (dohledatelnost).

Typickým př́kladem vnějši formy mající minimální význam pro relativní závaznost soudního rozhodnutí, ale velmi důležité pro jeho roli jako součásti judikatury, je postavení př́slušného soudu v hierarchii soudní soustavy. Pro relativní závaznost soudního rozhodnutí je lhostejné, který soud vydal pravomocné rozhodnutí, avšak pro jeho význam jako součásti judikatury je údaj o instanci zcela zásadní.

Vnější forma soudního rozhodnutí podstatná pro jeho roli $\mathrm{v}$ rámci judikatury zahrnuje celou řadu parametrů, přičemž řada $\mathrm{z}$ nich je zcela mimo kontrolu soudu, který toto rozhodnutí vydal. Typicky pasivní citace které významně promlouvají do výsledné praktické důležitosti soudního rozhodnutí, jsou výsledkem činnosti soudů často odlišných od toho, který odkazované rozhodnutí původně vydal. Podobně třeba zařazení soudního rozhodnutí do některé ze zákonných sbírek nemusí být v gesci vydávajícího soudu jako celku ale nějakého jeho zvláštního grémia. ${ }^{21}$

${ }^{20}$ Pro vady interní formy se v našem právním prostředí vžila, především v důsledku judikatury nejvyšších soudů a Ústavního soudu, různá typická označení, jako např́ílad nepřezkoumatelnost nebo opomenutý důkaz.

${ }^{21}$ Srovnání způsobů, jimiž proces výběru a editace judikatury k publikaci probíhá na nejvyšších evropských správních instancích, viz v publikaci Molek, P., Polčák, R. Poskytnout nebo chránit? Brno: Nejvyšší správní soud, 2017, str. 53. 
Praktickou důležitost soudního rozhodnutí mohou dokonce často definovat i prvky vnější jeho formy, jejichž původci nedisponují žádnou vrchnostenskou legitimitou. Př́kladem mohou být třeba anotace nebo citace, pozitivní či negativní, odbornou literaturou.

Nikoli přímo praktickou důležitost, ale samotnou dohledatelnost soudního rozhodnutí mohou zásadním způsobem ovlivňovat též jiné více či méně arbitrární prvky vnější formy, jako například právní věty nebo indexy. Neadekvátní a téměř až posvátných charakter právních vět ${ }^{22}$ svádí $\mathrm{v}$ našem právním prostředí $\mathrm{k}$ dojmu, že tyto jsou součástí vnitřní formy soudního rozhodnutí a v procesu editace judikatury dochází pouze $\mathrm{k}$ jejich zdůraznění. Soudci sami pak často trpí pod tíhou odpovědnosti, když se snaží cizelovat formulace $\mathrm{v}$ odůvodnění $\mathrm{s}$ vidinou toho, že se příslušná věta může, to právě kvůli neadekvátnímu jejímu užití, stát $\mathrm{v}$ důsledku jejího „právního zvětnění“ čímsi jako apendixem zákonného práva.

Ve skutečnosti je však právní věta pouze indikátorem potenciálního významu soudního rozhodnutí pro judikaturu a je součástí jeho vnější formy. Může samozřejmě jít o vhodně formulovanou součást odůvodnění př́slušného rozhodnutí. Může ji ale legitimně formulovat, dokonce zcela nezávisle na vnitřní formě př́slušného soudního rozhodnutí, též nezávislý editor, anotátor nebo komentátor. Klidně pak může dojít $\mathrm{k}$ situaci, kdy je $\mathrm{k}$ jednomu soudnímu rozhodnutí formulováno více právních vět $\mathrm{v}$ závislosti na tom, jakého konkrétního aspektu aplikace práva si př́slušný editor, anotátor nebo komentátor všímal.

Podobnou funkci jako právní věty mají též různé dodatečně doplňované indexy. Ty mohou např́klad indikovat vztah $\mathrm{k}$ zákonné úpravě nebo $\mathrm{k}$ judikatuře, tuzemské nebo zahraniční - to dokonce i v př́padech, kdy tento vztah není součástí vnitřní formy soudního rozhodnutí. Informační systém zpracovávající judikaturu, at jde o systém soudu nebo nějaké komerční řešení, tedy může soudní rozhodnutí označit i vztahovými atributy, které soud původně nevyjádřil, nebo o nich dokonce ani neuvažoval.

${ }^{22}$ Srov. Bobek, M., Kühn, Z. a kol. Judikatura a právní argumentace, 2. vyd. Praha: Auditorium 2013, str. 238. 
Především dopad externí formy na výslednou praktickou důležitost judikatury může vypadat pochybně vzhledem $\mathrm{k}$ legitimitě jednotlivých původců. Zatímco soud je alespoň legitimován $\mathrm{k}$ původnímu rozhodnutí, nedisponuje nezávislý editor informačního systému nebo autor právnické publikace žádným typem oficiální legitimace. Dokonce ani v případě, pokud je externí forma soudního rozhodnutí důsledkem aktivity samotného soudce (tj. soudce třeba formuluje právní větu nebo doplňuje indexy), není tato výrazem původní legitimace soudu $\mathrm{k}$ rozhodnutí ve věci.

Právě v tomto ohledu je však třeba zdůraznit shora konstatovaný rozdíl mezi relativní závazností soudního rozhodnutí a jeho praktickou důležitostí jakožto součásti judikatury. Soud je totiž v kontinentální právní kultuře př́mo legitimován pouze $\mathrm{k}$ relativnímu zavazování, nikoli $\mathrm{k}$ tvorbě práva. ${ }^{23}$ Praktická důležitost judikatury tedy $\mathrm{v}$ tomto př́padě nevychází $\mathrm{z}$ autority soudu, ale $\mathrm{z}$ obecných principů rovnosti a právní jistoty. Intenzita těchto principů pak není pro další př́ípady otázkou autority soudu a z ní odvozené právní moci rozhodnutí, ale je dána situační koherencí všech možných relevantních vlivů, včetně arbitrární pozornosti právní doktríny, kvality nástrojů pro automatizované zpracování judikatury nebo dokonce souvislostí se zahraniční právní úpravou či judikaturou.

Právě uvedené samozřejmě neznamená, že by měl kontinentální soudce s klapkami na očích ostentativně odmítat cizí nebo i vlastní úvahy o tom, jak se jeho rozhodnutí dál obecně projeví v právní praxi. Právě provedený kategorický soud snad až příliš příkře připomínající roli soudce $\mathrm{v}$ systému založeném na dělbě moci vzešlé z francouzské revoluce, je zde spíš reakcí na realitu českého souzení. V ní soudce vrcholného soudu, nikoli výjimečně a nikoli důvodně, sužuje sám sebe palčivými myšlenkami na všechny možné eventuality různých možných budoucích interpretací svého rozhodnutí nebo dokonce jeho právních vět. $\mathrm{V}$ horších případech pak tím, co soudce autonomně staví do nepř́slušné role tvůrce práva, může dokonce být jeho vlastní touha po zanechání vlastní stopy v právním řádu hnaná

${ }^{23}$ Srov. Bobek, M., Kühn, Z. a kol. Judikatura a právní argumentace, 2. vyd. Praha: Auditorium 2013, str. 66. 
navíc vědomím, že případ, který mu to aktuálně umožnil, už třeba nemusí nikdy dostat na stůl.

\section{INFORMAČNÍ EFEKTY VNĚJŠÍ FORMY SOUDNÍHO ROZHODNUTÍ}

Informační efekt různých formálních důsledků následného zpracování soudního rozhodnutí se samozřejmě neomezuje pouze na jeho roli jako součásti judikatury. Odborná publikace nebo jiná forma přiblížení soudního rozhodnutí odborné veřejnosti může i vyvolat veřejný zájem o určitý problém nebo třeba zvýšit známost nebo odbornou reputaci příslušného soudce. I v případě problematického nebo dokonce vyloženě vadného soudního rozhodnutí může mít ve výsledku odborná publikace i pozitivní informační efekt - to například v případě, kdy je součástí vnější formy argumentovaná identifikace vady, případně ještě doplněná o návod $\mathrm{k}$ řešení. ${ }^{24}$ Přestože tedy problematické soudní rozhodnutí chaotizuje svůj primární cílový systém tím, že vadně upraví právní poměry účastníků řízení, může v důsledku jeho adekvátního následného zpracování (včetně publikace) dojít k obecnému informačnímu efektu spočívajícímu třeba v následné korekci vadného procesního postupu nebo vyjasnění adekvátní interpretace hmotného práva.

K informačnímu efektu může vedle odborné externí formy soudního rozhodnutí vést i jeho populární užití. Typickým př́kladem je v tomto směru mediální prezentace soudního rozhodnutí. Na rozdíl od odborné publikace nemá mediální prezentace vliv na praktickou důležitost soudního rozhodnutí ani na jeho dostupnost (dohledatelnost). Soudní rozhodnutí totiž samozřejmě nezíská na odborném uznání tím, že si je jako obecně zajímavé vybere nějaké populární médium. Podobně ani populární publikace obvykle nevede $\mathrm{k}$ tomu, že by se zvýšila dohledatelnost soudního rozhodnutí. Mediálně zajímavé případy se totiž obvykle dotýkají věcí, které by byly dostupné odbornému publiku i bez mediální pozornosti.

24 Srov. Bogoch, B., Peleg, A. Carping, Criticizing and Circumventing: Judges, the Supreme Court and the Media in Israel, in Davis, R., Taras, D. (eds.) Justices and Journalists, Cambdridge: Cambridge University Press, 2017, str. 164. 
Informační či naopak entropický efekt zpracování soudního rozhodnutí $\mathrm{v}$ takovém případě samozřejmě odpovídá kvalitě novináře a nátuře publika. ${ }^{25} \mathrm{~V}$ porovnání s odbornou publikací nebo jinou externí formalizací soudního rozhodnutí je nutno předložit je veřejnosti $v$ atraktivním zpracování nevyžadujícím rozsáhlé předvědění ohledně okolností příslušného př́ípadu ani platného práva. Takové zjednodušení s sebou samozřejmě nese úskalí zkratky a jeho důsledkem může docela snadno být i neúmyslná nebo dokonce záměrná manipulace publika. Zvláštním případem jsou $\mathrm{v}$ tomto směru případy soudů, které se $\mathrm{z}$ různých důvodů snaží různými nástroji zprostředkovaně ovlivňovat svi̊j mediální obraz. ${ }^{26}$

Relativně novým druhem populární publikace soudního rozhodnutí je, podobně jako $\mathrm{v}$ jiných mediálně vděčných oblastech typu zdravotnictví nebo školství, justiční verze takzvané datové žurnalistiky. ${ }^{27}$ Jedná se o publikaci různých analýz vzniklých zpracováním primárních dat, tj. zejm. rozhodovací praxe a různých metadat generovaných justičními orgány. Tyto empiricky se tváŕící sekundární statistiky se mohou týkat kvality rozhodovací činnosti, efektivity nebo jiných snadno srozumitelných atributı̊ justiční aktivity. Vcelku snadno tak lze např́iklad ukazovat různé korelace, které díky velikosti zdrojových datových souborů mohou dokonce působit dosti věrohodným dojmem. ${ }^{28}$

Typickým příkladem může být třeba korelace mezi denní dobou a výší ukládaných trestů. Na tisících případů z české právní praxe lze empiricky doložit, že tresty ukládané při jednáních konaných před obědem jsou

25 Komplexní srovnávací pohled na problematiku populárního referování o rozhodovací činnosti soudi̊ přinesl sborník Davis, R., Taras, D. (eds.) Justices and Journalists, Cambdridge: Cambridge University Press, 2017.

26 Srov. Harada, S. The „Uncomfortable Embrace“: The Supreme Court and the Media in Canada, in Davis, R., Taras, D. (eds.) Justices and Journalists, Cambdridge: Cambridge University Press, 2017, str. 81.

${ }^{27}$ K pojmu datové žurnalistiky a jejím právním souvislostem viz Baranetsky, V. Data Journalism and the Law, Tow/Knight Report, Columbia Journalism School, 2018, dostupné ze cjr.org.

28 Obtížnost úkolu informovat v mediální zkratce o soudním rozhodování dokládá mimo jiné i existence celosemestrálního speciální kursu, který na toto téma pořádá Shorenseinovo centrum Harvardské univerzity nebo rozsáhlý portál „A Journalist's Guide to the Federal Courts“ provozovaný americkým ministerstvem spravedlnosti. 
nepoměrně tvrdší než ty, které soudy ukládají v odpoledních hodinách. Důvodem v tomto případě samozřejmě není frustrace hladových soudců, ale skutečnost, že ráno a dopoledne se obvykle projednávají tzv. vazební věci, tj. zpravidla závažnější trestné činy, jejichž obžalovaní pachatelé jsou $\mathrm{k}$ soudu předváděni $\mathrm{z}$ vazby. Tato podstatná informace však z mediální zkratky může vypadnout stejně snadno, jako z ní pravidelně vypadávají důležité faktory třeba $\mathrm{u}$ různých populárních žebříčků úspěšnosti advokátů nebo úmrtnosti ve zdravotnických zařízeních.

Justiční datová žurnalistika samozřejmě nemusí vést pouze $\mathrm{k}$ manipulaci publika. Vhodně zvolená statistika může ukazovat též na reálně existující problémy rozhodovací činnosti soudů. Díky dostupnosti judikatury a dalších justičních dat lze na základě analýzy odhalit třeba i neefektivní procesy nebo podezřelé anomálie. Vše v tomto případě záleží, ostatně jako kdekoli jinde, na schopnostech a vůli novináře posoudit adekvátnost př́islušných statistických korelací. ${ }^{29}$

Zvláštním typem vnějšího informační efektu hromadného zpracování soudních rozhodnutí je kontrola rozhodovací činnosti soudů. V demokratickém právním státě je samozřejmě tato kontrola svěřena instančně nadřazenému soudu a ve vybraných specifických otázkách mimo vlastní rozhodovací činnost případně též orgánu justičního dozoru. $\mathrm{V}$ režimech se zamlženou nebo otevřeně neexistující dělbou moci však může automatizované zpracování soudních rozhodnutí poskytnout vysoce efektivní nástroj k plošné autoritativní kontrole rozhodovací činnosti soudi̊.

Efektivní kontrola soudnictví stála i za rozvojem právní informatiky vjustičním systému komunistického Československa. Zakladatel československé právní informatiky, Viktor Knapp, k tomu v roce 1963 píše $\mathrm{e}^{30}$ : „Logická kontrola tedy přes omezenost svých možností je důležitým prostředkem nejenk přesnění statistických údajů, ale může být, jak již uvedeno, dost významným prostředkem kontroly dodržování socialistické zákonnosti.

${ }^{29}$ Blíže viz např. Bradshaw, P. Data Journalism, in Zion, L. Craig, D. Ethics for Digital Journalists: Emerging Best Practices, New York: Routledge, 2015, str. 202.

30 Viz Knapp, V. O možnosti použití kybernetických metod v právu. Praha : Nakladatelství Československé akademie věd, 1963, str. 20. 
Poněvadž pak logická kontrola, byt’ zatím nebyla prováděna kybernetickými stroji, nepochybně náleži $k$ celkovému procesu použití kybernetické metody $v$ soudní statistice, lze jistě bez nadsázky ř́ci, že praxe a zkušenosti v justiční statistice ukázaly pozoruhodnou novou stránku použití kybernetických metod $v$ právu a ukázaly zejména i to, že rozvážné jejich použití na vhodném místě může sloužit i velmi důležitým cílům politickým, jakým je bez jakékoli pochybnosti kontrola zachovávání socialistické zákonnosti.“

Knapp od svých původních vizí automatizace ideologické kontroly justice postupně ustoupil. Ještě v půli osmdesátých let se však vyskytovaly publikace připomínající využitelnost právních informačních technologií a informačních metod pro aktivní distribuci komunistické ideologie v justici. O dvacet let později, než Knapp nastínil vizi automatizované logické kontroly jako metody plnění politického zadání, tak píše tehdejší ředitelka Odboru řízení a justiční informatiky Ministerstva spravedlnosti SSR v časopise Socialistické súdnictvo, že: „...sa zabezpečí riešenie a realizácia podsystému úloh vyplývajúcich z usnesení najvyšších straníckych a štátnych orgánov ČSSR a SSR, týkajúcich sa činnosti justicie $v$ SSR a vytvorí sa automatizovaný informačný systém spracúvania a vyhodnocovania verbálnych informácií pre potrebu riadiaciej činnosti Ministerstva spravedlivosti $S S R .{ }^{31 ،}$

\section{LEGITIMITA TLAKU NA KONZISTENCI SOUDNÍHO ROZHODOVÁNÍ}

V důsledku technických možností hromadného zpracování dat z rozhodovací činnosti soudů se v posledních letech začíná i v demokratickém právním státě objevovat kvalitativně nový problém tlaku na nezávislost soudního rozhodování. Na rozdíl od shora popsané autoritářské kontroly rozhodovací činnosti však jde $\mathrm{v}$ tomto případě spíše o autonomní motivaci soudce indukovanou technologicky determinovanou reflexí dosavadní rozhodovací praxe.

31 Viz Colotková, Z. Rozvoj automatizovanej sústavy justičněj informatiky. Socialistické súdnictvo, roč. 37, č. 9,1985 , str. 1 . 
Typově tento tlak odpovídá shora zmíněnému břemeni, kterému čelí soudce rozhodující $v$ případě, o němž lze důvodně předpokládat, že výrazným zpo̊sobem promluví do judikatury. Soudce je v takovém případě autonomně motivován $\mathrm{k}$ tomu nepřemýšlet jen o předmětném př́ípadě, ale anticipovat i další užití svého rozhodnutí v obecných souvislostech principů rovnosti a právní jistoty.

Efekt anticipované praktické důležitosti soudního rozhodnutí samozřejmě nemá, resp. nesmí, ovlivnit výrok. Pokud by totiž byl výrok rozhodnutí určen namísto okolností konkrétního případu spíše anticipovanou budoucí aplikací příslušného rozhodnutí, jednalo by se o evidentní rozpor s právem na zákonného soudce a obecně s právem na spravedlivý proces (k obecnému problému s principem dělby moci viz výše). Účastníci řízení by totiž $\mathrm{v}$ takovém případě mohli oprávněně namítat, že soudce zde ve skutečnosti nerozhodoval o jejich právech, ale o nějakých hypotetických budoucích případech. Zprostředkovaný tlak principů rovnosti a právní jistoty projevuje se zde spíš v konstrukci odůvodnění, jehož zamýšleným adresátem nemusí být jen účastníci řízení nebo nadřízený soud, ale může jím být též okruh všech možných potenciálních adresátů příslušných právních pravidel.

Výše zmíněný nový typ tlaku působený hromadným zpracováním dat produkovaných soudy jde $\mathrm{v}$ tomto směru ještě dál a může se, i přes veškerou snahu soudce, reálně projevit dokonce i v samotném rozhodování o právech, tj. v konstrukci výroků. Velmi snadno se totiž dají zpracovat např. data mapující různé souvislosti rozhodovací činnosti každého jednotlivého soudce, a to za libovolně dlouhou dobu. Vedle víceméně jednoduchých statistik ukazujících třeba na výkonnost soudce, mohou být předmětem datové analýzy i velmi komplexní otázky samotného rozhodovací činnosti včetně vývoje jeho právních názorů, inspirace odbornou či jinou literaturou, způsobů reakce na rušící rozhodnutí vyšší instance apod.

V soudcovské profesi, kde je osobní i profesní konzistentnost brána za ultimativní ctnost, může mít tento typ datové transparentnosti fatální 
důsledky. ${ }^{32}$ Může totiž vést $\mathrm{k}$ vědomému nebo podvědomému potlačování těch složek soudcovského rozhodování, které, přestože se staví jakoby na odpor vůči shora opakovaně zmiňovaným principům rovnosti a právní jistoty, mají v systému justice a práva jako takového nezastupitelné místo kreativity a intuice. ${ }^{33}$

Problém vztahu mezi konzistentností soudce na jedné straně a jeho kreativitou a intuicí na straně druhé samozřejmě není v právu ničím novým. Jedná se o standardní projev generického konfliktu mezi dvěma ze tří fundamentálních účelů práva, tj. Jistotou a spravedlností. V kontinentální evropské právní kultuře je regulatorní kreativita a intuice svěřena do rukou zákonodárce a až jeho prostřednictvím (resp. prostřednictvím neurčitého pojmu) pak je k realizaci jejích projevů vyzván soudce. Neznamená to však, že by se měl soudce zabývat jen „slepou dedukcí “ vedoucí $\mathrm{k}$ „mechanické jurisprudenci. ${ }^{34 \text { “ }}$

Je z podstaty vadné domnívat se, že evropský soudce musí být při výkladu neurčitého pojmu nebo jiné právní metafory $\mathrm{v}$ čase dokonale konzistentní. Pokud by časová konzistentnost výkladu byla vůlí zákonodárce, vyžádal by si ji přeci autoritativně konkrétním pojmem nebo jeho legální definicí. Užití neurčitého pojmu naproti tomu dokonce přímo zakládá povinnost soudce průběžně posuzovat, i na základě vlastní zkušenosti a intuice, zda není důvod přehodnotit kvůli (nikoli nutně objektivně evidentním) měnícím se okolnostem jeho význam. Soudce, který na základě toho, že v čase nabývá životní zkušenost či odborné znalosti nebo sleduje vývoj společnosti, průběžně mění názor na adekvátní

${ }^{32} \mathrm{Z}$ jiného úhlu pohledu se problémem motivace soudce konzistentností zabývají William Richman a William Reynolds v kritické práci Richman, W. M., Reynolds, W. L. Injustice on Appeal, Oxford: Oxford University Press, 2013, str. 95.

33 Mariusz Golecki píše o projevech kreativity a intuice jako o „emocích“ a argumentuje jejich nezastupitelnost v soudcovském rozhodování v kapitole Golecki, M. J. Between Nomos and Pathos: Emotions in Aristotelian Theory of Adjudication and the Dual Process Theory, in Huppes-Cluysenauer, L., Coelho, N. (eds.) Aristotle on Emotions in Law and Politics, Springer, 2018, str. 435.

34 Tento pojem užívá v souvislosti $s$ kritikou přehnaného tlaku na logickou konzistentnost soudního rozhodování Roger Cotterrell v práci Cotterrell, R. B. M., The Politics of Jurisprudence: A Critical Introduction to Legal Philosophy, Philadelphia: University of Pennsylvania Press, 1992, str. 158. 
interpretaci právních metafor, přitom samozřejmě nejedná ani v nějakém neproporcionálním rozporu s požadavkem právní jistoty nebo rovnosti před zákonem.

Přese všechno výše uvedené ale není žádnému normálně myslícímu soudci př́ijemná představa, že bude ve svém rozhodování evidentně nekonzistentní. Nejde $\mathrm{v}$ tomto př́padě ani tak o nějakou zásadní změnu názoru na otázky života a smrti, $\mathrm{k}$ níž by zřejmě u soudce skutečně nemělo dojít, ale o konzistentnost $\mathrm{v}$ partikulárních záležitostech marginálního významu, které však se přímo projevují při každodenním rozhodování konkrétních př́ípadů. Dostupnost dat o předchozí rozhodovací činnosti soudce a všech možných více či méně souvisejících metadat ve spojení se stále dokonalejšími analytickými nástroji totiž umožňují stavět soudce před zrcadlo vlastní konzistentnosti i v sebemenší drobnosti. Pod vlivem takového tlaku pak může racionalita, tj. Konzistentnost, u soudce vcelku snadno zvítězit nad jeho intuicí či kreativitou.

Technologií motivované vítězství konzistentnosti nad intuicí nemusí se jevit na první pohled nijak problematicky. Ve fungování mechanismu právní regulace však jde o přinejmenším diskutabilní systémové vychýlení rovnováhy mezi třemi Radbruchovými účely ve prospěch jistoty na úkor (nejisté) spravedlnosti a (rovněž nejisté) praktické užitečnosti. ${ }^{35}$ Pohledem výše zmíněných základních premis právní informatiky pak je omezení intuice či kreativity ve prospěch konzistentnosti dokonce jednoznačně vadné, protože brání přirozenému projevu unikátní schopnosti života reagovat na změnu (aktuální nebo očekávanou) produkcí originální informace. $^{36}$

Shora popsaný vysoce problematický charakter hloubkové analýzy rozhodovací činnosti soudů jdoucí na úroveň jednotlivých soudců reflektuje z demokratických právních států jako první na světě aktuální francouzská zákonná úprava. ${ }^{37} \mathrm{Ta}$ zakazuje takovou práci s daty pocházejícími ze soudní rozhodovací praxe (tj. se soudními rozhodnutími a dalšími

35 Srov. Schmidt, A. Radbruch in Cyberspace: About Law-System Quality and ICT Innovation. Masaryk University Journal of Law and Technology, 2009,č. 3(2), str. 195.

${ }^{36}$ Srov. Wiener, N. Cybernetics: Or the Control and Communication in the Animal and the Machine. Cambridge : MIT Press, 1961, str. 11. 
metadaty), která ve výsledku vede k profilování soudců za účelem předvídání budoucího jejich rozhodování. Příslušné ustanovení má následující podobu (překlad RP): „Zpracování osobních údajů soudců nebo soudních úředníků za účelem srovnávání nebo předvídání jejich skutečné nebo domnělé úrední činnosti se zakazuje.“

Tento kategorický zákaz, stíhaný dokonce trestní sankcí, se stal př̀edmětem rozhořčené kritické debaty v Evropě i USA. ${ }^{38}$ Kritici této úpravě nejčastěji vyčítají fatální neproporcionalitu vzhledem k právu na svobodu informací (včetně práva získávat a zpracovávat údaje o činnosti orgánů veřejné moci) a právu na svobodu projevu. Pohledem právní informatiky však $\mathrm{k}$ takovému zákazu profilování existuje docela dobrý důvod, a to shora popsané neadekvátní zesílení tlaku principů rovnosti a právní jistoty a omezení možnosti a povinnosti soudce zapojit do rozhodování též z podstaty nejistou a nepředvídatelnou spravedlnostní intuici. Čím kvalitnější totiž bude systém predikující z dosavadních údajů budoucí rozhodovací praxi (ve smyslu komplexnosti dat a sledovaných parametrů), tím složitěji bude muset soudce vůči tomu, kdo nebude spokojen s příslušným rozhodnutím, argumentovat odchýlení se od jeho predikce založené výlučně na empirické analýze a logické extrapolaci stávající rozhodovací praxe.

Nabízí se v tomto směru srovnání například s diagnostickými systémy užívanými v medicíně. Zde se autonomní algoritmy vcelku úspěšně používají například v oblasti diagnostiky nádorových onemocnění. Platí ale přitom, že i špičkový systém založený na rozsáhlé datové základně a vyspělé autonomní technologii nikdy nedosáhne kvality špičkového lidského diagnostika, který vedle empirických poznatků a zkušenosti používá též počítači nedostupnou metodu originální (kreativní) tvorby diagnostické informace. ${ }^{39}$

37 Viz čl. 33 zákona o reformě justice ze dne 23. března 2019 (LOI n 2019-222 du 23 mars 2019 de programmation 2018-2022 et de réforme pour la justice), dostupný na www.legifrance.gouv.fr.

38 Viz např. Langford, M. Madsen, M. R. France Criminalises Research on Judges, verfassungsblog.de, 22 červen 2019. 
Dosavadní zkušenost s použitím této technologie ukazuje, že její nasazení tam, kde je k dispozici kvalitní lékař, může být ze statistického hlediska kontraproduktivní - lidský lékař je totiž nucen zdo̊vodňovat pacientovi případnou svoji odchylnou diagnózu, to dokonce pod tíhou vlastní odpovědnosti. Ve výsledku pak může dokonce dojít k tomu, že se role vymění, lékař rezignuje na kreativitu a pouze kontroluje, zda úsudek systému nevykazuje nějaké fatální nedostatky.

Je-li francouzský zákaz diskutabilní, není to dle našeho názoru problém premisy ale přinejhorším jen použité metody řešení neadekvátního tlaku na nezávislost soudce. Francouzský právotvůrce zde zakázal zpracování justičních údajů a publikaci rozhodovacích predikcí, tj. vydal se cestou absolutního omezení dostupnosti empirických dat hodnotících konzistentnost rozhodovací činnosti soudce. Jinou možností, vyžadující však změnu chápání principu rovnosti a právní jistoty ve spojení s pragmatickou reflexí adekvátního významu neurčitého pojmu a jeho vývoje včase, je akceptace určité míry explicitně nezdůvodněné nekonzistence. To se může týkat samotného rozhodování nebo i jen jeho odůvodňování.

V tomto případě francouzský právotvůrce naznal, že adekvátním řešením problému technologicky determinovaného tlaku na nezávislost soudu je eliminace příslušné technologie, což je diskutabilní přístup typově podobný prohibici. Na druhou stranu jde však $\mathrm{v}$ tomto případě o pochopitelnou snahu reagovat, byt̉ možná až př́liš opatrně, na hrozbu nezávislosti justice, o jejíž závažnosti, resp. toxicitě, zatím nemáme odpovídající poznatky. Vcelku pochopitelná je $\mathrm{v}$ tomto případě též zjevná nedůvěra francouzského právotvůrce $\mathrm{v}$ instantní evoluci relativně tradicionalistické francouzské právní kultury ve smyslu shora zmíněné změny chápání principů rovnosti a právní jistoty, resp. možností jejich oslabení pouze $\mathrm{v}$ důsledku běhu času. Pokud zde tedy francouzský právotvůrce dospěl $\mathrm{k}$ pragmatickému závěru, že dostupnost nástrojů

39 Viz např. Miller, D. D., Brown, E. W. Artificial Intelligence in Medical Practice: The Question to the Answer? The American Journal of Medicine, roč. 131,č. 2, str. 129 nebo Krittanawong, C. The rise of artificial intelligence and the uncertain future for physicians, European Journal of Internal Medicine,č. 48, str. 13. 
profilujících soudy a soudce vzhledem $\mathrm{k}$ jejich rozhodovací činnosti přinese víc škody (shora popsaným neadekvátním tlakem na nezávislost soudního rozhodování) než užitku (ten by zde zřejmě spočíval $\mathrm{v}$ těžko předem definovatelném zvýšení míry transparentnosti justice), těžko lze tomuto závěru něco zásadního vytknout.

\section{SHRNUTÍ}

V tomto př́spěvku jsme se zabývali problematikou informačního efektu automatizovaného zpracování judikatury. Dospěli jsme zde k nikoli překvapivému závěru, že informační efekt judikatury je dán kombinací informační kvality př́slušných soudních rozhodnutí a mechanismu jejich následného zpracování.

Konkrétně jsme se věnovali informační analýze podstatných rozdílů mezi soudním rozhodnutím (judikátem) a judikaturou jakožto pramenem práva. Upozornili jsme $\mathrm{v}$ tomto ohledu na problém legitimního primárního účelu soudního rozhodnutí, kterým je organizovat systém účastníků řízení. Informační efekt judikatury jako pramene práva je pak až sekundárním projevem nikoli př́imo soudního rozhodnutí jako takového (nebo dokonce jeho právní věty), ale informačního komplexu ustálené rozhodovací praxe a různých aspektů její informační expozice veřejnosti.

Zvlǎštní pozornost jsme věnovali též novým vysoce přesným metodám hloubkové prediktivní analýzy rozhodovací činnosti konkrétního soudce nebo úřední osoby. Všímali jsme si potenciálního informačního, resp. entropického, efektu této relativně nové technologie, která se již stala předmětem vysoce diskutabilní zákonné restrikce. Dospěli jsme v tomto směru k závěru, který úplně nekoresponduje s aktuální mezinárodní kritikou, a to že tato restrikce nepředstavuje evidentní regulatorní exces a může být pragmaticky důvodná a právně legitimní.

\section{SEZNAM POUŽITÉ LITERATURY}

[1] Alexy, R. On the Structure of Legal Principles. Ratio Iuris. 2000, roč. 13, č. 3.

[2] Baranetsky, V. Data Journalism and the Law, Tow/Knight Report, Columbia Journalism School, 2018, dostupné ze cjr.org. 
[3] Bobek, M., Kühn, Z. a kol. Judikatura a právní argumentace, 2. vyd. Praha: Auditorium 2013.

[4] Bogoch, B., Peleg, A. Carping, Criticizing and Circumventing: Judges, the Supreme Court and the Media in Israel, in Davis, R., Taras, D. (eds.) Justices and Journalists, Cambdridge: Cambridge University Press, 2017.

[5] Bradshaw, P. Data Journalism, in Zion, L. Craig, D. Ethics for Digital Journalists: Emerging Best Practices, New York: Routledge, 2015.

[1] Cole, B. Shepardizing: A Comparison of the Printed Citators and On-Line Shepardizing Services. Legal Reference Services Quarterly. 1988, roč. 7, č. 2-4.

[2] Colotková, Z. Rozvoj automatizovanej sústavy justičněj informatiky. Socialistické súdnictvo, roč. 37, č. 9, 1985.

[3] Cotterrell, R. B. M., The Politics of Jurisprudence: A Critical Introduction to Legal Philosophy, Philadelphia: University of Pennsylvania Press, 1992.

[4] Davis, R., Taras, D. (eds.) Justices and Journalists, Cambdridge: Cambridge University Press, 2017.

[5] Golecki, M. J. Between Nomos and Pathos: Emotions in Aristotelian Theory of Adjudication and the Dual Process Theory, in Huppes-Cluysenauer, L., Coelho, N. (eds.) Aristotle on Emotions in Law and Politics, Springer, 2018.

[6] Harada, S. The „Uncomfortable Embrace“: The Supreme Court and the Media in Canada, in Davis, R., Taras, D. (eds.) Justices and Journalists, Cambdridge: Cambridge University Press, 2017.

[7] Holländer, P. Filosofie práva. Plzeň : Aleš Čeněk, 2006.

[8] Kelsen, H. Pure theory of Law, New Jersey: The Lawbook Exchange, 2005.

[9] Knapp, V. O možnosti použití kybernetických metod v právu. Praha: Nakladatelství Československé akademie věd, 1963.

[10] Knapp, V. Teorie práva. Praha: C.H. Beck, 1991.

[11] Krittanawong, C. The rise of artificial intelligence and the uncertain future for physicians, European Journal of Internal Medicine, č. 48.

[12] Langford, M. Madsen, M. R. France Criminalises Research on Judges, verfassungsblog.de, 22 červen 2019.

[13] Miller, D. D., Brown, E. W. Artificial Intelligence in Medical Practice: The Question to the Answer? The American Journal of Medicine, roč. 131, č. 2.

[14] Molek, P., Polčák, R. Poskytnout nebo chránit? Brno: Nejvyšší správní soud, 2017. 
[15] Neff, V. Filozofický slovník pro samouky aneb Antigorgias. Praha: Mladá fronta, 1993.

[16] Paliwala, A. A History of Legal Informatics. Zaragoza : Prensas de Universitarias de Zaragoza, 2010.

[17] Polčák, R. Informační teorie práva, in Bobek, M., Molek, P., Šimíček, V. Komunistické právo v Československu, Brno: Masarykova univerzita, 2009.

[18] Polčák, R. Internet a proměny práva, Praha: Auditorium, 2012, str. 23.

[19] Richman, W. M., Reynolds, W. L. Injustice on Appeal, Oxford: Oxford University Press, 2013.

[20] Schmidt, A. Radbruch in Cyberspace: About Law-System Quality and ICT Innovation. Masaryk University Journal of Law and Technology, 2009, č. 3(2).

[21] Schrödinger, E. What is Life. Cambridge : Cambridge University Press, 1992.

[22] Wiener, N. Cybernetics: Or the Control and Communication in the Animal and the Machine. Cambridge : MIT Press, 1961.

Toto dílo lze užít v souladu s licenčními podmínkami Creative Commons BY-SA 4.0 International (http://creativecommons.org/licenses/by-sa/4.0/legalcode). 